\section{(6) OPEN ACCESS}

\title{
Marketing 'less harmful, low-tar' cigarettes is a key strategy of the industry to counter tobacco control in China
}

\author{
Gonghuan Yang
}

\begin{abstract}
Correspondence to
Professor Gonghuan Yang, Department of Epidemiology and Statistics, Institute of Basic Medical Science, Chinese Academy of Medical Science, 5\# Dong Dan San Tiao, Beijing 100005, People's Republic of China; yangghuan@vip.sina.com
\end{abstract}

Received 22 July 2012 Revised 20 December 2012 Accepted 21 December 2012 Published Online First 24 January 2013

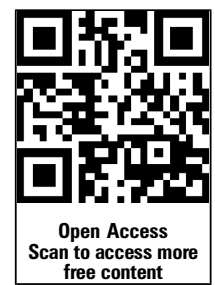

To cite: Yang G. Tob Control 2014;23:167-172.

\begin{abstract}
While the 'low-tar' scheme has been widely recognised as a misleading tactic used by the tobacco industry to deceive the public about the true risks of cigarette smoking, a similar campaign using the slogan of 'less harmful, low tar' was launched by the Chinese tobacco industry, that is, State Tobacco Monopoly Administration/ China National Tobacco Corporation and began to gain traction during the last decade. Despite the fact that no sufficient research evidence supports the claims made by the industry that these cigarettes are safer, the Chinese tobacco industry has continued to promote them using various health claims. As a result, the production and sales of 'less harmful, low-tar' cigarettes have increased dramatically since 2000. Recently, a tobacco industry senior researcher, whose main research area is 'less harmful, low-tar' cigarettes, was elected as an Academician to the prestigious Chinese Academy of Engineering for his contribution to developing 'less harmful, low-tar' cigarettes. The tobacco researcher's election caused an outcry from the tobacco control community and the general public in China. This paper discusses the Chinese tobacco industry's 'less harmful, low-tar' initiatives and calls for the Chinese government to stop the execution of this deceptive strategy for tobacco marketing.
\end{abstract}

\section{'LESS HARMFUL, LOW-TAR' STRATEGY IN CHINA}

Since the early 1960s, faced with increasing concerns over health risks among smokers, the tobacco industry has developed low-tar cigarettes to encourage health-concerned smokers to switch brands instead of quitting. ${ }^{1}$ Such deceptive tactics from the industry have been widely exposed, and it has been ruled in lawsuits that 'low-tar' cigarettes are perhaps the greatest fraud ever perpetrated on consumers in history. ${ }^{2}$ The use of words such as 'low-tar', 'mild' and 'light' that contribute to consumer misconceptions about disease risks should be banned in advertising and on cigarette packaging.

However, despite the fact that these descriptive terms have been banned in many other countries as deceptive and misleading to consumers, 'less harmful, low tar' is today an important strategy for the tobacco industry in China. Annual meeting reports on tobacco and cigarettes since 2000 reveal that the State Tobacco Monopoly Administration (STMA), the government administrative body overseeing the tobacco industry, and the Chinese National Tobacco Corporation (CNTC), proposed to 'actively proceed with 'less harmful, low-tar' cigarettes'. They sought to improve the sophistication of technical innovations as a strategy to turn smokers' health concerns into a business opportunity, and to reverse a sales decline. At the 2000 annual meeting of STMA, a report noted that the tobacco industry had experienced much hardship in $1999^{3}$ due to an over-supply of higher priced cigarettes and the saturation of the tobacco market. One key task of the STMA in 2000, therefore, was to promote its ability to compete while addressing the challenges of smoking's effects on health. Article 5 of the Law of the People's Republic of China on Tobacco Monopoly states that 'The State shall strengthen the scientific research and technical development of tobacco monopoly commodities, so as to improve the quality of tobacco products and reduce the content of tar and other hazardous ingredients in such products'. ${ }^{4}$ Based on this requirement, 'science-based development' and 'reducing tar of cigarettes' have been key work products in each year's STMA annual meeting report since 2000. In 2003, the STMA developed the Chinese Cigarette Science and Technology Development Outline ${ }^{5}$; in 2006 the STMA ordered manufacturers to reduce tar in cigarettes to an average of $12 \mathrm{mg}$ by $2010 .{ }^{6}$ A report at the STMA annual meeting in 2010 noted that implementing the 'less harmful, low-tar' strategy would be the overall approach to improving competitiveness in China. ${ }^{7}$

At a forum on 'Developing Chinese-style Reduced Tar and Harm Cigarettes' held in Xiamen, Fujian province in 2004, the Deputy Director General of STMA, Zhang Baozhen, reiterated that the overall approach and strategic decisions in developing Chinese-style low-tar cigarettes with Chinese herbs mattered in the near future and to the overall fate of the Chinese tobacco industry. $\mathrm{He}$ encouraged all forum attendees to consider these links, saying, 'We need to study and reflect deeply (on) the relationships between reducing tar and harm, developing Chinese-style cigarettes, and the survival and development of the Chinese tobacco industry, ${ }^{8}$

Following the strategies set forth in the STMA Scientific and Technologic Development Plan, four strategic programmes were launched: tobacco seedlings, cigarette flavouring, special processes, and reducing tar and harm. The STMA made significant investments in the latter every year. In 2009, 1.694 billion Yuan (a 27.4\% increase over 2008) ${ }^{9}$ was spent on tobacco science and technology research. Some of this research focused on adding Chinese herbal and flavour materials to tobacco, then manufacturing cigarettes that purportedly tasted better 
and reduced risk. ${ }^{10}$ During 2001-2008, 987 scientific papers on Modified Risk Tobacco Products were published, 685 papers from tobacco institutes, 233 from affiliations between tobacco institutes and other institutes. The research on low tar/low risk was carried out by the tobacco industry or others subsidised by or affiliated with the Chinese tobacco industry. ${ }^{11}$

\section{VALIDITY OF 'LESS HARMFUL, LOW-TAR' RESEARCH CALLED INTO QUESTION}

Most of the 'low-tar' and Chinese-style cigarette research studies were sponsored by STMA/CNTC or carried out by industry researchers. These studies evaluated the safety of cigarettes through either chemical analysis of tobacco smoke collected using the International Organisation for Standardisation (ISO)/the USA Federal Trade Commission (FTC) methods or toxicological studies of tobacco smoke in animal experiments unrelated to health effects. These studies, however, have not been conducted in humans using internationally recognised approaches to health risk evaluations, and they do not include observational studies or long-term clinical experiments in humans. None of these studies provided any evidence to demonstrate that use of 'less harmful, low-tar' cigarettes actually reduced health risks and addiction for consumers of the products compared with regular cigarettes. ${ }^{12}{ }^{13}$ Meanwhile, findings from research conducted by independent researchers produced evidence in the opposite direction. Two recent studies compared the urine metabolites of nicotine and tobacco carcinogens in smokers who smoked regular cigarettes and those who smoked purportedly 'less harmful' cigarettes. These studies showed that the Chinese 'low-tar' and herbal cigarettes did not deliver lower levels of nicotine and carcinogens than regular cigarettes. $^{1415}$

Even among tobacco industry researchers, no consensus exists on whether smoking low-tar cigarettes leads to harm reduction. A study conducted by an industry researcher determined the tar and carcinogens such as benzo(a)pyrene and nitrosamine of cigarette smoke across nine brands. The results indicated that the content of tar of cigarette smoke in each brand was not correlated with the levels of carcinogens, and the levels of benzo(a) pyrene and nitrosamine in some low-tar cigarettes were even higher than in cigarettes with regular tar levels. ${ }^{16}$

\section{THE 'TOBACCO ACADEMICIAN'}

One of the pioneer researchers on 'less harmful, low-tar' cigarettes in China is Xie Jianping, a senior tobacco researcher and the Deputy Director of the Zhengzhou Tobacco Research Institute, a research organisation directly affiliated with and supported by the CNTC. Mr Xie JP graduated from the Department of Chemistry of Nanjing Normal College, received the Bachelor of Science in 1982, then studied at the Institute of Tobacco Industry Science and was awarded the Master of Engineering in $1985 .^{17}$

Xie's research on developing a hazard index for cigarettes and evaluating 'less harmful, low-tar' cigarettes was based on the outdated ISO/FTC method, ${ }^{18}$ which underestimated smokers' actual intake of toxins from low-tar cigarettes. Xie's evaluation of the safety of 'less harmful, low-tar' cigarettes also failed to assess their health impacts on humans. Instead, chemical analysis of the residual tobacco smoke on filters under the ISO/FTC method was used as the sole criterion. Xie insisted that 'This research method screened cigarette smoke toxic components with toxicity index ... If we set the risk index of cigarettes in China in 2008 at 10, then the risk indices in 2009 and
2010 are 9.7 and 9.3 respectively. The overall trend is clearwe are making progress in harm reduction'. ${ }^{19}$

Even though there is no substantial evidence demonstrating actual reduction in risk from 'less harmful, low-tar' cigarettes, researchers from the tobacco industry have won six national scientific awards in harm reduction during the last decade, including three awards related to research on low-tar cigarettes led by Xie Jianping: research on improving burley tobacco quality and its application in low-tar cigarettes $(2003)^{20}$; research on technologies that reduce toxic components in cigarette smoke $(2004)^{21}$; and establishing a cigarette hazards evaluation and control system and its application (2010). ${ }^{22}$

In December 2011, Xie was elected to the renowned Chinese Academy of Engineering (CAE) as an Academician, the highest honour for a scientist in China. During the past year, the controversy surrounding Xie's qualifications as a tobacco industry researcher and the validity of his scientific achievements has caused a public outcry and a frenzy of media attention. ${ }^{23} \mathrm{Xie}$ himself was dubbed by the media the 'Tobacco Academician'. ${ }^{24}$ Concerns have been raised over the legitimacy of the review procedures for Xie's application to CAE. Although Xie's research was closely related to public health, he did not have the sponsorship of the Ministry of Health (MOH) for his application to CAE. In fact, all his sponsorship came from the STMA/CNTC. Many felt that because Xie's main scientific achievements were health related, there should be physicians or public health experts on his review committee. But in fact, Xie's qualifications were reviewed only by the members from the Division of Environment and Textile of the CAE, none of whom had medical or public health training. As the controversy surrounding Xie continued, the national scientific awards he received in the past were also called into question as the awards were sponsored solely by the STMA/CNTC without health experts' academic accreditation or recommendation from the $\mathrm{MOH}^{25}$

After being debated for half a year, in May, about 100 academicians of the CAE petitioned to review Xie's research achievements, and reconsidered his validation as a qualified academician. $^{26}$ The 11th Academician Congress of CAE took place on 11 June 2012, but New Academician Xie JP was not invited to attend, and his Academician qualification remained up for debate. ${ }^{27}$ The news report pointed out: 'Xie's supporters in CAE believed that the Regulation of CAE must be stringently

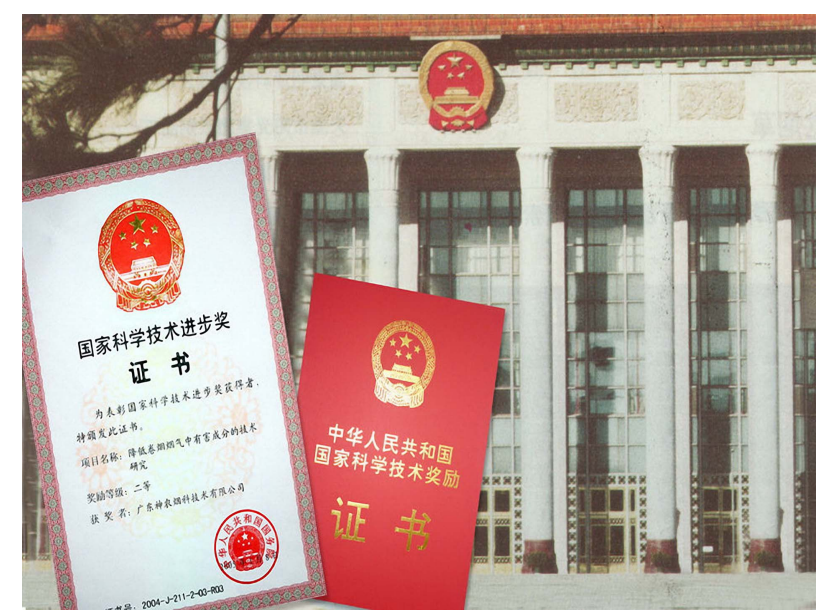

Figure 1 Certification of National Scientific and Technological Progress Award with Bio-Reducing Technology of Cigarettes on the WU YE SHEN cigarettes website. 
Figure 2 Cigarette products of Chinese Tobacco Industry, 1952-2011 (data source: Network of Industry in China, http://www.chinair.org/data/ D08/201007/01-46830.htm/).

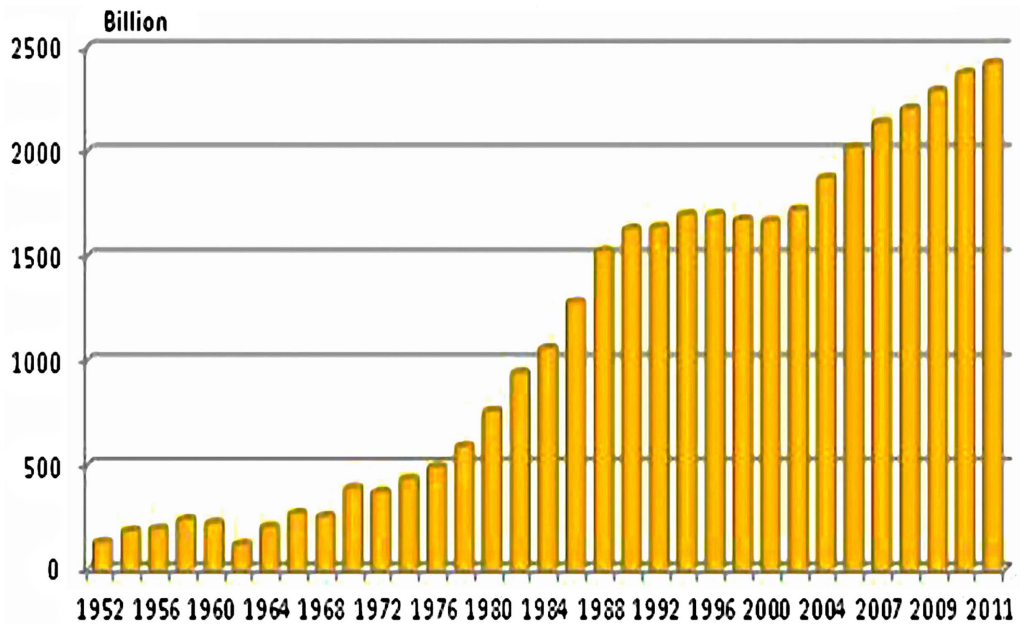

observed. The procedure of electing the New Academician has been completed, in their view; it cannot be changed arbitrarily'. At the time this paper was written, CAE was still considering this issue and had made no decision.

\section{MARKETING OF 'LESS HARMFUL, LOW-TAR' CIGARETTES}

Xie's awards become a marketing tool of the Chinese tobacco industry $^{28}$ (figure 1).

National cigarette sales had declined in the 1990s until the tobacco industry launched the 'less harmful, low-tar' strategy in 2000. Since then, the key tobacco industry economic and technological indicators have improved. ${ }^{29}$ In 2009, overall tobacco production was recorded at 2.29015 trillion sticks (45.803 million boxes) and sales were at 2.28875 trillion sticks (45.775 million boxes), an increase of nearly $40 \%$ in tobacco production and sales compared with 2000 (figure 2)..$^{30} 31$ Production and sales of low-tar cigarettes have also recorded far more rapid growth than expected. During the first 10 months of 2011, low-tar cigarette production in China was 2.8947 million boxes, an increase of $408 \%$, and sales were at 2.8704 million boxes, an increase of $386 \%$ compared with the year before. ${ }^{32}$ 'Low-tar' cigarettes sales grew about 10 times as fast as those of all cigarette products.

\section{MISCONCEPTIONS ABOUT 'LESS HARMFUL, LOW TAR' ARE STILL COMMON IN CHINA}

In the 2010 Global Adult Tobacco Survey in China, participants were asked: 'Do you agree that low-tar cigarettes are less harmful than regular cigarettes?' The survey results indicated that $86 \%$ of respondents were not aware that 'low tar' did not mean 'less harmful', including $35.8 \%$ who were unaware and $50.2 \%$ who said that they were not sure. ${ }^{33}$

The survey results also indicated that those with higher education tended to believe in the industry's claims about 'low tar'. Over $45 \%$ of the respondents with a college education and above agreed with the industry claims, unaware that low-tar cigarettes are as harmful to health as regular cigarettes (figure 3). A similar pattern was observed with occupation, and

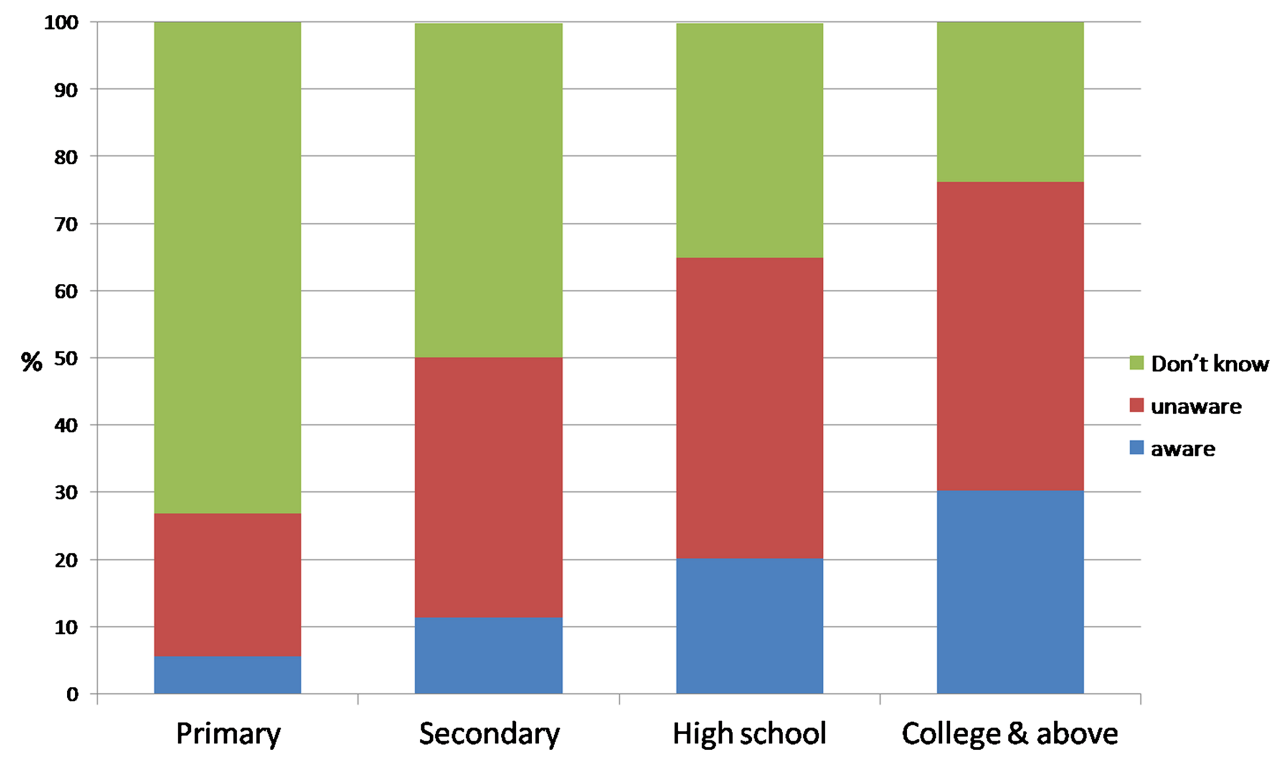

Figure 3 Awareness that low-tar cigarettes are as harmful to health as regular cigarettes by education. 


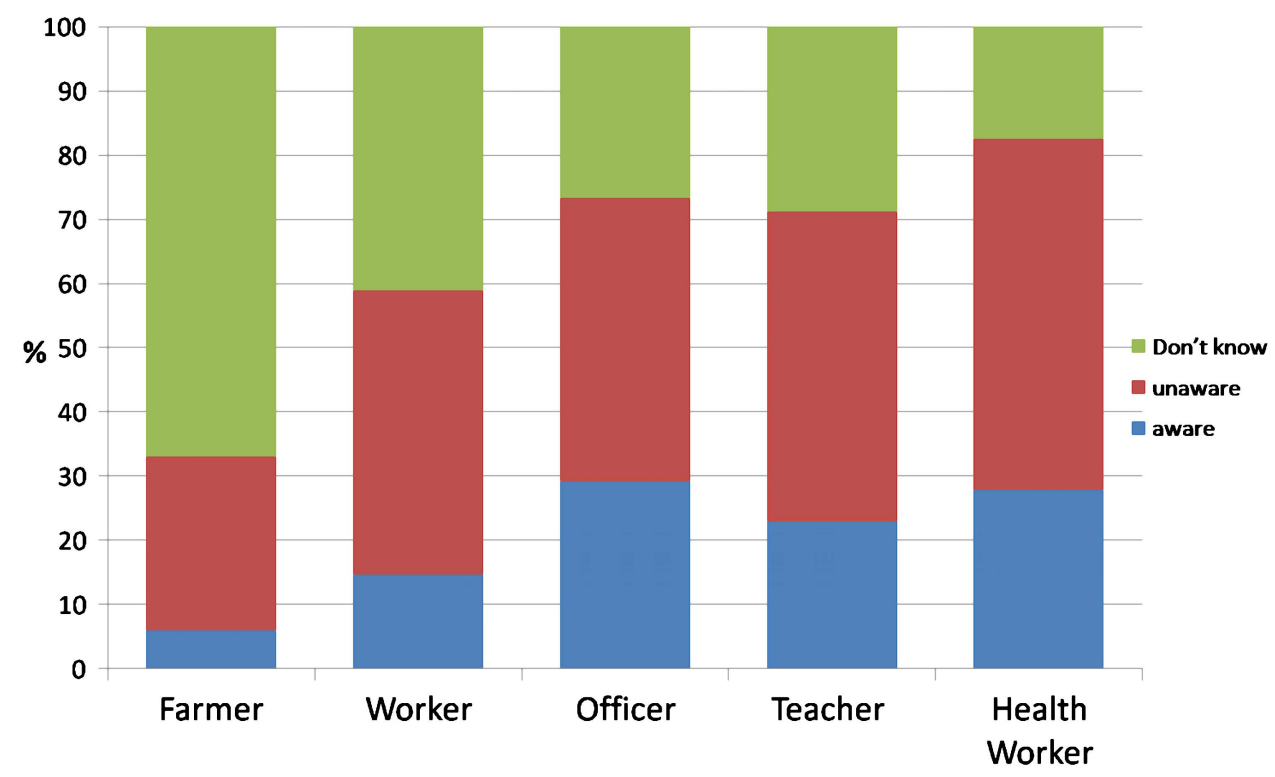

Figure 4 Awareness that low-tar cigarettes are as harmful to health as regular cigarettes by occupation.

the highest rate of misconception (54.7\%) was observed among medical professionals (figure 4). This indicates that the 'less harmful, low-tar' tactic used by the tobacco industry to counter tobacco control has indeed paid off, and suggests the critical importance of challenging the industry's misinformation.

STMA promote 'less harmful, low tar' to counter implementation of the WHO Framework Convention on Tobacco Control (the WHO FCTC) which was adopted unanimously at the 56th World Health Assembly in 2003. The Chinese Government signed the FCTC on 8 November 2003 and the 17th session of the 10th National People's Congress ratified the WHO FCTC on 27 August 2005. ${ }^{34}$ The FCTC became effective in China on 8 January 2006.

Since 2000, the STMA has paid more attention to the impact of the FCTC on the tobacco industry. The STMA approved research on the WHO FCTC and countermeasures to address its impacts on the Chinese tobacco industry. ${ }^{35}$ The results were published in $2008 .^{36}$ and the publication was praised by STMA as a proactive initiative. ${ }^{37}$

The FCTC's Article 11 calls for parties to prohibit the use of terms like 'low tar', 'light', 'ultra light' or 'mild'. The industry book suggested using blue or green colours to represent the same meanings. Article 11 also requires the health warning to be approved by the competent national authority. The industry strategy book suggests that 'national authorities' should be the STMA.

Article 11 also calls on parties to ensure that each unit and package of tobacco products shall contain information on relevant constituents and emissions of tobacco products as defined by national authorities. Based on this requirement, the industry book recommends that the STMA/CNTC mark the content of tar, nicotine and carbon monoxide. The industry recommendation has become the domestic regulation on packaging and labelling of cigarette packages in the name of implementing the WHO FCTC in China ${ }^{38}$ (figure 5).

One of the most critical tobacco control measures is to stop the involvement of tobacco companies in public health policies, as mandated by the WHO FCTC Article 5.3, which states: 'In setting and implementing their public health policies with respect to tobacco control, Parties shall act to protect these policies from commercial and other vested interests of the tobacco industry in accordance with national law'. ${ }^{39}$ Because the industry (CNTC) and the government administrative agency (STMA) are virtually the same organisation, policies introduced
Figure 5 The visible figures of tar content are marked on the front of cigarette packs in China (source: collected and provided by the author).
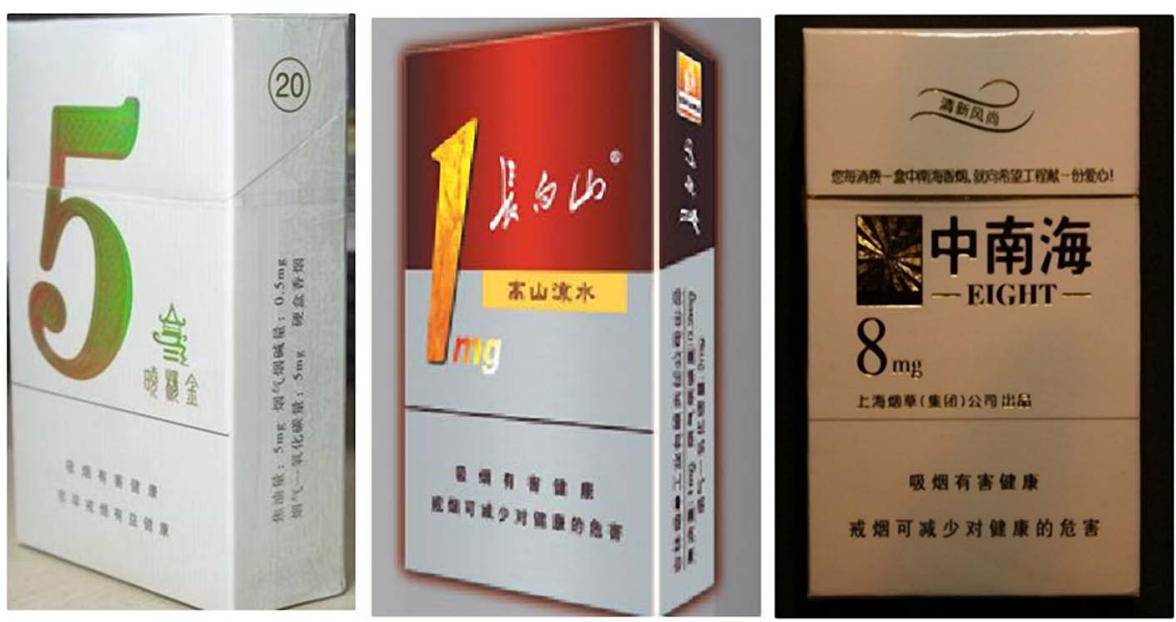
by the STMA in the name of the Chinese government are often de facto anti-tobacco control strategies. This is perhaps the biggest challenge that tobacco control faces in China.

In 2008, the WHO China Office stated ${ }^{40}$ 'In China 'reducing tar and harm' is publicised as (a) tobacco control achievement, but (it) is actually a big lie to mislead consumers by the industry'. The STMA/CNTC uses and abuses its national administrative power to adopt and implement its 'less harmful, low-tar' strategy.

\section{POLICY RECOMMENDATIONS}

To effectively implement Article 11 of the FCTC, the State Council should endow the State Food and Drug Administration (SFDA) with the power to regulate all tobacco products, including purported Modified Risk Tobacco Products (MRTPs). The authority to review and approve MRTPs before they are marketed should also be transferred to the SFDA. The State Administration for Industry and Commerce and General Administration of Quality Supervision, Inspection and Quarantine should address the misleading safety claims being made by STMA/CNTC. Also Article 5 of the Law of the People's Republic of China on Tobacco Monopoly should be revised, as it obviously conflicts with WHO FCTC. Finally, the government should support research to investigate the role of STMA/CNTC in disseminating safety and health claims about 'less harmful, low-tar' cigarettes. The Chinese government should not permit a replay of the 'less harmful, low-tar' deceptions that have already been exposed after costing millions of lives in other countries.

\section{Key messages}

- Previous studies have found that cigarettes marketed as 'low tar' are not less harmful and in many countries, tobacco companies are barred from using such deceptive descriptors. However, such marketing practices continue in China, where the state tobacco company and the state tobacco regulator operate in tandem.

- This paper describes the tactics used by the Chinese tobacco industry to increase cigarette sales by promoting low-tar and 'herbal' cigarettes as healthier alternatives to conventional cigarettes, sponsoring the nomination of an industry researcher on low-tar cigarettes for the renowned Chinese Academy of Engineering, and working to undermine provisions of the WHO FCTC.

- Given that research suggests that even health professionals believe the 'low-tar-less-harm' lie, challenging these industry claims is critical for tobacco control efforts in China.

Acknowledgements The author thanks Dr Ruth Malone for giving recommendations and help with editing this manuscript. The author also acknowledges the anonymous Chinese-speaking reviewer who provided very careful editing help and suggestions for organising the manuscript.

Contributors The author conceived the idea and wrote the whole manuscript.

Funding This work was supported by NIH project 'Epidemiology and Intervention Research for Tobacco Control in China' (R01 RFA-TW-06-006).

Competing interests None.

Ethics approval This study was conducted with the approval of the Institute of Basic Medical Sciences of the Chinese Academy of Medical Sciences.

Provenance and peer review Not commissioned; externally peer reviewed.
Open Access This is an Open Access article distributed in accordance with the Creative Commons Attribution Non Commercial (CC BY-NC 3.0) license, which permits others to distribute, remix, adapt, build upon this work non-commercially, and license their derivative works on different terms, provided the original work is properly cited and the use is non-commercial. See: http://creativecommons.org/ licenses/by-nc/3.0/

\section{REFERENCES}

1 National Cancer Institute. Risks Associated With Smoking Cigarettes with Low Machine-measured Yields of Tar and Nicotine. Smoking and Tobacco Control Monograph no. 13. Bethesda, MD: US Department of Health and Human Services, National Institutes of Health, National Cancer Institute, 2001.

2 Judge Kessler Final Opinion. United States v. Philip Morris. Civil Action Number 99-2496 (GK), 2006. http://www.tobaccolawcenter.org/documents/FinalOpinion.pdf (accessed 31 Jan 2013).

3 Ni YJ. 2000 Annual Meeting on Tobacco. http://www.echinatobacco.com/101588/ 102220/102333/102336/32117.html (accessed 31 Jan 2013).

4 National People's Congress. Law of the People's Republic of China on Tobacco Monopoly, the order of the President of the People's Republic of China (Seventh Section, the 46th) promulgated by Order No. 46 of the President of the People's Republic of China on 29 June 1991 and effective as of 1 January 1992. http://www. people.com.cn/item/flfgk/rdlf/1991/111703199107.html (accessed 31 Jan 2013).

5 STMA. Middle-Long Term Science and Technology Develops Outline of Chinese Tobacco Industry (2006-2020). http://www.tobacco.gov.cn/history_filesystem/ 07zzcx/ltbj-1.htm (accessed 20 Mar 2012).

6 STMA. The notice on promoting to improve risk of cigarettes by further reducing tar content. State tobacco (2006) 412. http://www.tobaccoinfo.com.cn/zhxx/szgdgg/ 2006/06/25477.shtml (accessed 31 Jan 2013).

7 Jiang CK. 2010 Annual Meeting on Tobacco. http://www.tobaccochina.com/news/ China/highlight/20101/20101206213_392774.shtml (accessed 20 Mar 2012).

8 Zhang BZ. Speech on the Forum on Development of Chinese Style Cigarette with Low Tar and Less Harm: Paying Attention to the Public Health, Promoting Harmony, 2004 Development. http://www.tobaccoinfo.com.cn/ztxw/2010/04/33312.shtml (accessed 31 Jan 2013).

9 Jiang CK. The Report on 2009 National Tobacco Working Conference. 13 January 2009. http://www.tobacco.gov.cn/history_filesystem/2009gzh/news1.html (accessed 31 Jan 2013)

10 Wang YT, Xie JP, Zhang $H$, et al. Technology research and application on reducing the harmful ingredients of cigarettes smoke. Acta Tabacaria Sinica 2003;9:1-7.

11 Liu XZ. Pernicious effect on the tobacco control from harm reduction of cigarette by tobacco industry. http://cdmd.cnki.com.cn/Article/CDMD-84501-2009203572.htm (accessed 20 Mar 2012).

12 Zhu MX, Yang SH, Cao ZS, et al. Cell biological evaluation for Sheng Nong extraction on reducing harmfulness of smoking. Chinese Tobacco Academic Annual Meeting, 2002. http://wenku.baidu.com/view/c65f5124bcd126fff7050bd3.html (accessed 31 Jan 2013).

13 Xie JP, Liu HM, Zhu MX, et al. The Index Research on Hazards of Cigarette Smoke. Tob Sci Technol 2009;2. http://www.cnki.com.cn/Article/CJFDTotal-YCKJ200902001. htm (accessed 31 Jan 2013).

14 Gan Q, Goniewicz M, Benowitz NL, et al. Chinese 'low-tar' cigarettes do not deliver lower levels of nicotine and carcinogens. Tob Control 2010;19:374-9.

15 Gan Q, Yang J, Benowitz NL, et al. Chinese 'herbal' cigarettes are as carcinogenic and addictive as regular cigarettes. Cancer Epidemiol Biomarkers Prev 2009;18:3497-501.

16 Du YM, Xia XZ, Wang YB. The smoke tar and safety of the cigarettes. Chin Tob Sci 2002;(2):31-4. http://mall.cnki.net/magazine/Article/ZGYV200202009.htm (accessed 31 Jan 2013).

17 Baidu Baike Baike Namecard Xie Jianping. http://baike.baidu.com/view/2908328. htm\#1 (accessed 20 Mar 2012).

18 World Health Organization (WHO). Scientific Advisory Committee on Tobacco Product Regulation. SACTob Conclusions on Health Claims Derived from ISO/FTC Method to Measure Cigarette Yield. Geneva: WHO, 2003. http://www.who.int/ tobacco/sactob/recommendations/en/iso_ftc_en.pdf (accessed 20 Mar 2012).

19 Wang CC. The new development for the Chinese cigarette. Chin Tob 2011;444(3). http://www.echinatobacco.com/zhongguoyancao/2011-02/01/content_250361.htm (accessed 31 Jan 2013).

20 Ministry of Science and Technology, P. R. China. List of National Scientific and Technological Progress Awards. 2003: No. J-211-2-03. Research on improving burley tobacco quality and its application in low-tar cigarettes. http://www.most.gov. cn/cxfw/kjilcx/kjjl2003/200802/t20080214_59048.htm (accessed 20 Mar 2012).

21 Ministry of Science and Technology, P. R. China. List of National Scientific and Technological Progress Awards. P. R. China: Ministry of Science and Technology, 2004. No. 54. Technology research and application on reducing the harmful ingredients. http://www.most.gov.cn/cxfw/kjjlcx/kjj|2004/200802/t20080214_59054 .htm (accessed 20 Mar 2012)

22 List of National Scientific and Technological Progress Awards. P. R. China: Ministry of Science and Technology, 2010. No. 41. Establishing cigarette hazards evaluation and control system and its application. http://www.most.gov.cn/ztzl/gjkxjsjldh/ jldh2010/jldh10jlgg/201101/t20110115_84315.htm (accessed 20 Mar 2012). 
23 Hvistendahl M. Tobacco scientist's election tars academy's image. Science 2012;335:153-4.

24 Tobacco research scholar became the academician, which caused network argue, called Xie 'tobacco academician dispute'. South Daily. http://china.nfdaily.cn/ content/2011-12/09/content_34672668.htm (accessed 20 Mar 2012).

$25 \mathrm{MOH}$ of P. R. China. Press release, 12. April 2012 http://www.moh.gov.cn/publicfiles/ business/htmlfiles/mohbgt/s3582/201204/54488.htm (accessed 31 Jan 2013).

26 About 100 Academicians ask reviewing Xie' reconsider his validation as a qualified Academician. Xinhua News. http://news. 163.com/12/0530/02/82NHNTV000014 AED.html (accessed 31 Jan 2013).

27 'Tobacco Academician' was not invite to attend the 11th Academician Congress of CAE, CAE will continue to discuss his qualification. South Metropolis Daily 2012. http://gcontent.oeeee.com/1/49/14919153f8aaf3af/Blog/f04/5269ac.html (accessed 31 Jan 2013).

28 Wu-Ye-Shen Cigarette: Hu Dong Bai Ke. http://www.hudong.com/wiki/\%E4\%BA\% 94\%E5\%8F\%B6\%E7\%A5\%9E\#7 (accessed 20 Mar 2012).

29 Feng WS. Summary on the low tar cigarette market in 2011. Tob China. http:/l www.tobaccochina.com/management/market/analyse/201112/2011123083226 496628.shtml (accessed 20 Mar 2012).

30 Zhou RZ. The course of 50 years of China tobacco. China Tob 1999;18. http://uww. echinatobacco.com/101588/102220/102320/102351/32484.html (accessed 31 Jan 2013).

31 Chinese commercial information. China cigarettes product, 2001-2010. http://pdf. askci.com//viewdata187311.pdf (accessed 31 Jan 2013).

32 Zhang Y. Marketing low-tar cigarettes to start new era of digging gold nuggets. New Tobacco 2011:21. http://www.echinatobacco.com/xinyancao/2011-11/01/ content_292532.htm (accessed 31 Jan 2013).
33 Chinese Center for Disease Control and Prevention. Global Adults Tobacco Survey (GATS) China 2010 Country Report. Beijing, China: San Xia Press, 2011.

34 The Central People's Government of the People's Republic of China. Tobacco control for 5 years. http://www.gov.cn/fwxx/content_1780112.htm (accessed 20 Mar 2012).

35 Jiang CK. Preamble one: advance research to meet the requirement of decision-making. In: Zhou RZ, Cheng YZ, eds. Research on Countering Tactics for WHO Framework Convention on Tobacco Control and Impact from Tobacco in China. Beijing, China: Economic Science Press, 2006:1-3.

36 Zhou RZ, Cheng YZ. Research on Countering Tactics for WHO Framework Convention on Tobacco Control and Impact from Tobacco in China. Beijing, China: Economic Science Press, 2006.

37 Department of Science and Education. STMA. No. 06. Summary table of project winning award for science and technology of CNTC, 2008. http://www. tobaccoinfo.com.cn/images/2hxx/szgdgg/Uploadpdf/2009/20090330.doc (accessed 31 Jan 2013).

38 STMA, GAQSIQ. The domestic regulation on packaging and labeling of cigarettes package within P. R. China. http://www.gov.cn/gzdt/2008-04/10/content_941504. htm (accessed 20 Mar 2012).

39 WHO FCTC. Article 5.3 of WHO Framework Convention on Tobacco Control. http:/l www.who.int/fctc/protocol/guidelines/adopted/article_5_3/en/index.html (accessed 20 Mar 2012).

40 Xinhua-PR Newswire. Low-tar cigarettes as deadly as regular cigarettes, WHO Says, 2008. http://www.ecplaza.net/news/11/9341/lowtar_cigarettes_as.html (accessed 20 Mar 2012). 